\title{
Creating a New Business through Restructuring in a Socially Responsible Way
}

\author{
Doina I. Popescu and Ion Popa
}

The Bucharest University of Economic Studies, Romania

\begin{abstract}
The paper presents the impact of socio economic changes induced by the global financial crisis on the apparel industry in Romania that focuses largest number of SMEs in the industry. Article highlights the fact that in the new context, the companies from this domain must constantly adapt, creating a new business in order to pursue restructuring, and the importance of restructuring in a socially responsible manner.
\end{abstract}

Keywords: level of employment, staff retention, market niche, innovation, Romanian clothing industry, global economic crisis.

\section{Introduction}

The global economic crisis and its consequences have forced the world to face a prolonged employment crisis, a deepening of poverty and inequality. In 2009, ILO (International Labor Organization) estimates that over 34 million people were unemployed as a result of the crisis. Fighting unemployment and trying to achieve decent work by all should be a priority as the global economy is in the process of recovery.

The enormous social and economic changes from Europe in the recent years have had a significant impact on the business environment for companies, especially SMEs. Currently, to meet these changes and remain competitive, companies must constantly adapt and learn to innovate. Traditionally, the restructuring processes are generally regarded as causing job losses. However, in recent years - and as a result of the need to create more jobs and better EU initiatives under the Europe 2020 strategy there has been given more attention to creating a new business that pursues restructuring and the importance of "restructuring in a socially responsible manner".

In Romania, the unemployment rate rose to $8.5 \%$ in 2010 (more than 800,000 unemployed from the total labor force of 9.2 million active employees). This is just those registered at the National Employment Agency Employment, namely those who receive unemployment benefits. The period of unemployment aid varies between 6 and 12 months depending on seniority. This calculation assumes that in the number of unemployed people the people that their period has expired, but have not found employment are not taken into account.

The clothing industry in Romania is the most affected by the employment crisis. Unemployment increased, FEPAIUS (Employers' Federation of Light Industry of Romania), for example, estimated that over 71,000 workers lost their jobs in this period of crisis in different ways: firms went bankrupt; companies have reduced the production activities; employers who have moved production outside the EU etc. Thus,

Copyright (C) 2013 Doina I. Popescu and Ion Popa. This is an open access article distributed under the Creative Commons Attribution License unported 3.0, which permits unrestricted use, distribution, and reproduction in any medium, provided that original work is properly cited. Contact author: Doina I. Popescu E-mail: doinaipopescu@yahoo.com 
in the clothing industry in Romania, the number of employees decreased significantly in 2009 compared to 2008, with a significant increase in 2011 compared to 2010 (Table

1).

Table 1. Number of Employees

\begin{tabular}{|c|c|c|c|c|}
\hline & Year 2008 & Year 2009 & Year 2010 & Year 2011 \\
\hline Number of employees & 200.570 & 150.220 & 141.600 & 141.700 \\
\hline
\end{tabular}

Source: Ministry of Economy, Trade and Business Environment, 2011

In this context, Romania has become mainly an exporter of labor. Thus, in the present it is estimated that the number of people working abroad is about 2 million people. Meanwhile in Europe as well as in Romania the population is declining.

Pop et al (2010) believes that structural reforms essential for Romania's economic future, are far from the truth. Given the chronic deficit of labor force today, maintaining rigid regulations of excessive protection of workers is not only anachronistic but also acts against competition, competitiveness based on employment quality, growth of labor productivity of the main catch up factor Romania needs in the real convergence process. The employee exit barrier transforms into an entry barrier. Instead of stimulating the creation of new jobs, even unsecured, but with the necessary mobility, current labor legislation pushes a part of the working age population to migrate.

In addition, Kanter (2006) thinks that if companies will not offer positions to increase the value of learning, the mobility will be defined not by voluntary migration, but by painful dislocations that will affect people.

\section{Methodology}

The study begins by presenting the effects of global economic crisis on an innovative industrial sector, namely the clothing industry in Romania, of the impact of internationalization of SMEs on job creation, of the factors with significant impact on the evolution of the clothing market. Given that the clothing industry in Romania, with a long tradition and a significant share in the exports of Romania, and it concentrates the largest number of SMEs, we considered it a representative branch to identify the level of employment, the level of personnel maintenance in companies belonging to the industry amid the global economic crisis, which is why we conducted a questionnairebased investigation with a number of 192 companies in the industry. Also, there were identified strategies used by companies that have managed to maintain and even create new jobs in times of crisis. Future directions were elaborated to increase employment in the clothing Romanian companies. Besides the conducted study, the researchers collected information from professionals working in production and sales of apparel in Romania.

The Impact of the SME Internationalization on Job Creation

During 2009, The Directorate - General for Enterprise and Industry (DG ENTR) of the European Commission conducted the study "Internationalisation of European SMEs" to provide an exhaustive picture of their internationalization, highlighting issues such as: the impact of internationalization on job creation by SMEs, the link between internationalization and innovation.

The study had as respondents 480 SMEs from 33 European countries, from which 27 EU member states and 6 non-EU European countries. The most important results of the 
study showed that $25 \%$ of European SMEs exported goods in 2007, 2008 and 2009, the peak years of crisis. However international activities are directed at other countries of the internal market and only about $13 \%$ of European SMEs operated in foreign markets to the EU.

The importance of the study lies in the fact that it showed the need to support the internationalization process of SMEs for at least the following main reasons:

- International SMEs create more jobs (SMEs international activities have increased the number of employees by $7 \%$ compared to only $1 \%$, percentage registered by SMEs with no international activities);

- International SMEs are more creative (20\% of the SMEs with international activities have introduced new products and services, compared to only $8 \%$ in the case of the other SMEs);

- A significant percentage of European SMEs are more active internationally, compared to the U.S. and Japan (So, even if we consider only the extra EU exports and they still have better results).

Romania's Export Strategy for the clothing industry for 2010-2013 stipulates a gradual transition from lohn system to marketing and an own design to increase the opportunities for a complete business, under its own brand. In Romania, about 400 companies have their own brand, but are not well known abroad. Romania's Export Strategy recommends improving the international competitiveness of the clothing industry in Romania and the internationalization of SMEs in order to increase the number of jobs in the area.

The clothing industry in Romania, ranks third in Romania's exports, ranked fourth in EU exports, and concentrates the largest number of SMEs in the industry, so a large number of employees. Given that the largest share of micro and small firms (with small financial power), the export under their own brand can be achieved mainly by developing niche businesses.

Thus, small clothing firms in Romania can penetrate markets in which large firms show little interest or even zero interest in, thus avoiding competition with them. By applying this strategy, small businesses can become leaders in a small market or a niche market, rather than pursuing a large market.

Firms serving niche markets get to know the requirements and consumer expectations so well that they ensure a high level of satisfaction that creates a special affinity to a particular brand of product, or service, not only a rational preference.

Marketing management in the new context involves identifying key success factors on relevant market: innovation, financial strength, customer support, product quality, skilled labor, access to distribution channels, continuous monitoring of positioning strategies of competitors.

\section{Factors with a Significant Impact on the Evolution of the Clothing Market}

In a research study by Popescu and Popa (2012), they consider that in order to be competitive, the products of this industry must respond to the new concepts that the global economic crisis has imposed on this market. Thus, the concept of fast-fashion implies presenting 5-6 collections per year, instead of 2, small series and limited production to give the consumer a feeling of exclusivity, uniqueness, to satisfy his desire to break the ordinary pattern of the massmarket market.

In this context, manufacturers must provide new products to dealers every 3-4 weeks, which led to the emergence of new forms of commerce such as lean-retailing, small stocks and just-in-time supply.

Also, in the context in which on the background of global economic crisis, consumers became reluctant to shopping in 
general and more careful with clothing budget in particular, moving from the concept of "compulsory purchase" to "Do I really need?" this has led to the change of consumption patterns in the clothing industry. Consumers have become more pragmatic, less loyal to established brands and more interested in buying products during reductions of selling prices.

Reconfiguration of the value chain of clothing products, reconfiguration of the retail formats, continuous decrease, in the last years, of the clothing prices, increased international competition, changes in consumer perception regarding the buying decision of a textile product according to value, quality, ecological character, but also social responsibility of the manufacturer are challenges that the industry managers are required to meet.

Popescu et al (2009) mentioned that another main current that the economic crisis has initiated is that to promote quality clothing coming from brands that have as motivation the respect for traditions, and cultural influences. This trend, in conjunction with the development of own brands has led to the launch in November of 2011 by the $100 \%$ RO Association, of the $100 \%$ RO couture collection called "Prejudice", signed by the French designer Philippe Guilet (artistic director of the French Embassy in Bucharest) and carried out with the support of dozens of craftsmen and Romanian designers from Maramures and Bistrita (NorthWest development Region), Bucovina (NorthEast), Brasov (Central region) and Bucharest (Bucharest-Ilfov region). The collection was used as inspiration for the Romanian cultural heritage, and was called "Prejudice", because it defies negative stereotypes about Romanians. This collection was inspired by exclusively local sources. In fact, everything in this collection was Romanian, materials, resources, project team, besides the designer and developer. Thus, the collection was a reinterpretation, in a modern and surprising way of cultural elements, crafts and Romanian traditional objects, transforming these sources of inspiration in modern and sophisticated couture outfits. 100\%RO Association aims to implement cultural projects that highlight the Romanian cultural heritage. The purpose of these projects is to promote Romania, and to inspire the new artistic creations, for companies in the field.

Study on the Examination of Employment Status and Strategies Used by the Companies in the Clothing Industry in Romania, in the Context of Global Economic Crisis

In the present research we aim to bring an important contribution to both the theoretical and pragmatic aspect of the studied field. The need to examine the state of employment in the Romanian clothing companies is justified by the fact that this industry was most affected by the employment crisis. Examining the strategies used by companies in this field, in the context of the global economic crisis, reflects the extent to which they succeeded or not to maintain the number of employees and respectively to create new jobs or not.

To get necessary valid information regarding the state of employment in the Romanian clothing companies and to identify the strategies used by them in the context of global economic crisis, we have undertaken an investigation of opinion among these companies. The survey was based on a questionnaire given to managers of the analyzed firms.

This research aims at four main objectives:

Objective 1: Identification of production features and based on this of the extent to which clothing firms in Romania succeeded or not, to keep the number of employees, amid the global economic crisis;

Objective 2: Identification of problems with which the analyzed companies are facing with, in terms of maintaining, restraining or developing the activity in terms of the markets on which they operate on; 
Objective 3: Identification of the strategies used by the analyzed companies, amid the global economic crisis;

Objective 4: Substantiation the future directions of growth of the level of employment in the Romanian clothing companies.

The questions were structured into three sections.

General information about the analyzed companies.

This section contains general questions of identity, address, development region to which the business belongs to, establishment of size by number of employees, by way of capital, and by product destinations.

II. Information about whether or not firms were able to maintain the number of employees and respectively create or not new jobs in the context of new social and economic conditions.

The set of questions used in this section serves the most direct purpose of the research, the questions being aimed at identifying the respondents' opinion on the current state of employment, or to identify the extent to which the analyzed firms were able or not to keep the number of employees, to create or not new jobs, depending on the destination of products, form processing, the size of firms by the development region to which they belong to. The questions in this section also imply the identification of the strategies used by the analyzed companies, namely correlating them with the level of employment, depending on the destination of products, form processing, firm size, and the development region to which they belong to.

III. Future direction of growth of the level of employment in the Romanian clothing companies.

This section is very important because it presents the main ways of increasing the level of employment, and thus beginning an economic recovery of an innovative industrial sector.

The research was designed, conducted and analyzed by the authors.

\section{Sample of Surveyed Firms}

The questionnaire-based study was conducted on a number of 192 clothing companies for women and men from all the development regions of Romania, and covers the year 2011. Details on the territorial structure of the sample of investigated companies are presented in Table 2 .

Table 2. Distribution of the Sample by Development Regions

\begin{tabular}{|l|c|c|c|}
\hline No. Item. & Development region & $\begin{array}{c}\text { No. analyzed } \\
\text { companies }\end{array}$ & Percentage (\%) \\
\hline 1 & North-West & 30 & 15,63 \\
\hline 2 & North-East & 28 & 14,58 \\
\hline 3 & West & 23 & 11,98 \\
\hline 4 & Centre & 26 & 13,54 \\
\hline 5 & South-West & 14 & 7,29 \\
\hline 6 & South-East & 25 & 13,02 \\
\hline 8 & South & 24 & 12,50 \\
\hline 9 & Bucharest and Ilfov & 22 & 11,46 \\
\hline Total & & $\mathbf{1 9 2}$ & $\mathbf{1 0 0}$ \\
\hline
\end{tabular}


Graphical representation of the geographical respondent firms is presented in Figure 1. distribution by development regions of the

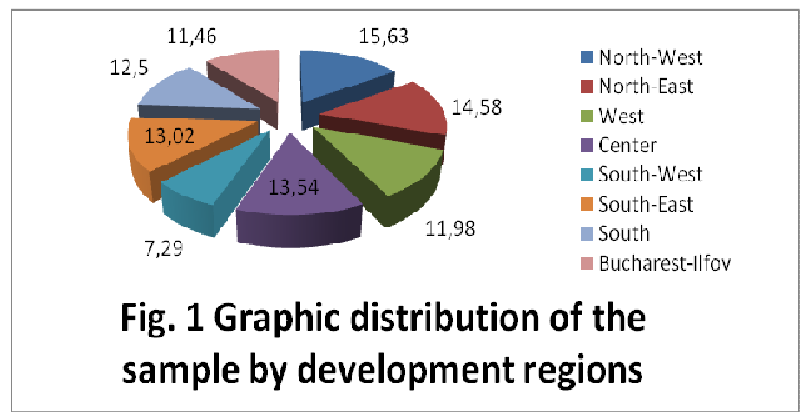

Presentation of the General Information about the Sample Companies

By way of capital, of the 192 companies, 23 are joint ventures with foreign capital, 169 are companies with Romanian capital (Fig. 2).

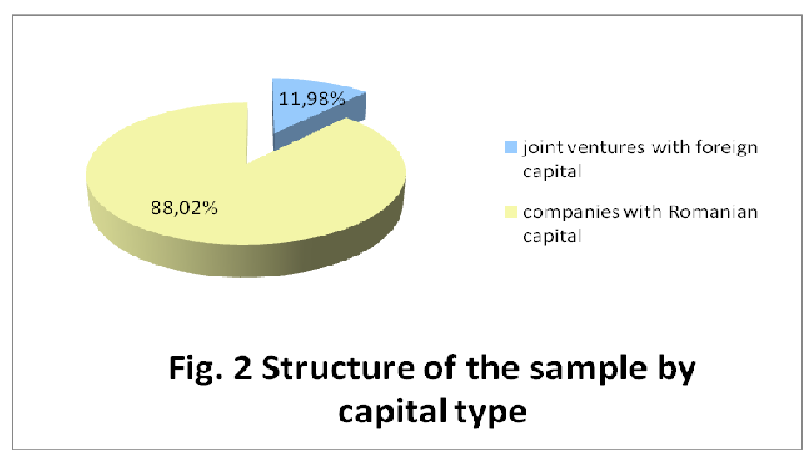

Structure of the companies by number of employees is presented Table 3 .

Table 3.Structure of the Companies by Number of Employees

\begin{tabular}{|c|c|c|c|c|}
\hline Total & $\begin{array}{c}\text { Large (over 250 } \\
\text { employees) }\end{array}$ & $\begin{array}{c}\text { Medium (50- } \\
\text { 249 employees) }\end{array}$ & $\begin{array}{c}\text { Small (10-49 } \\
\text { employees) }\end{array}$ & $\begin{array}{c}\text { Micro (1-9 } \\
\text { employees) }\end{array}$ \\
\hline 192 & 4 & 29 & 60 & 99 \\
\hline
\end{tabular}

It is noted that the share of micro firms in the analyzed sample is $51,56 \%, 31,23 \%$ small companies, medium companies $15,10 \%$, and large companies of 2,08\% (Fig.3). 


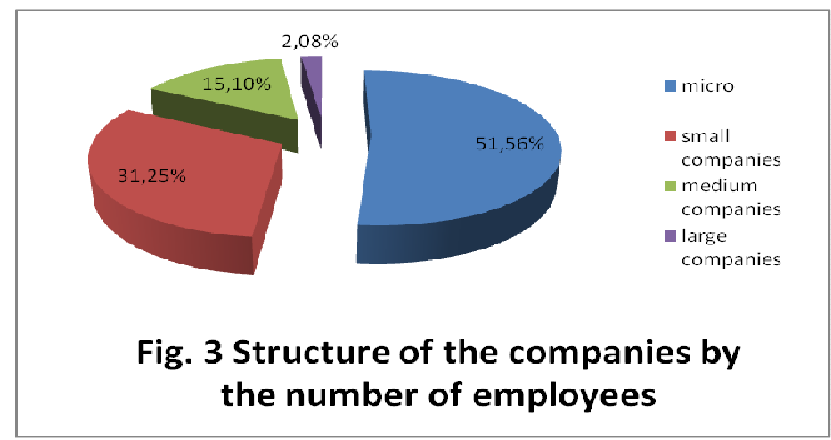

Following the destination of products, of the 192 companies, 115 exports, and the other 77 addresses the internal market with their own brands. Of the 115 exporting firms, 71 firms export their entire production in lohn system, 44 firms export in full-product; however the majority of full-product exports are sustained by processing in lohn system (Fig. 4).

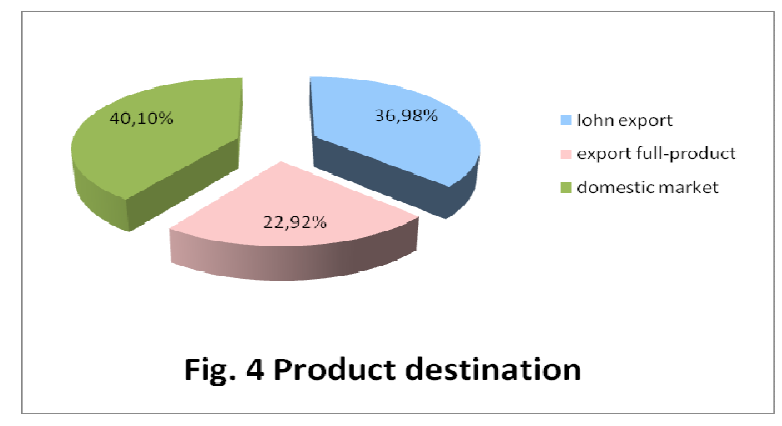

II. In matters relating to employment respectively maintaining the number of employees, especially since 2009, when economical crisis effects were felt significantly in Romania, and continuing with the years 2010, 2011, responses revealed that firms carrying out exports have succeeded in a significantly greater extent than the companies producing for the domestic market to maintain the staff. Among the companies that make export the full-product exporting are those that have maintained the staff in the largest share. Their managers claim they succeeded this, with no need to restrict their activity because they have developed over time internationally recognized brands with loyal customers.

The managers of firms that export in lohn system and which maintained the staff put this mainly to the fact that their companies have continued to have orders given that they can meet small orders (up to 2000 products) required by the customer in accordance with the fast-fashion concept. Companies in China are not interested in small orders and don't have their production capacities adapted to them.

In a study conducted in 2011 by MOD SPE Paris, about the implications of fast-fashion concept on production and retail, the following countries have been identified that can provide constant renewal of products in small quantities at intervals of 3-4 weeks, namely Morocco, Tunisia, Romania, Bulgaria, and to a lesser extent Ukraine.

Only three of the analyzed companies, namely exporting companies have created new jobs, all making full-product export. 
Most managers of firms producing for the domestic market say they were forced to give up some of their staff due to reduced activity due to low purchasing power in Romania, power affected even stronger since 2010, along with:

- Significantly increase in the number of unemployed;

- Diminishing the budgetary salaries by 25\%;

- Diminishing overall wages in the private sector by about the same percentage;

- Increase of VAT from 19 to 24\%.

Managers of companies that address the internal market and have maintained the number of employees, said that this was possible by ensuring a good price-quality ratio, promotional activities and using diverse channels of distribution such as: own distribution (the manufacturer is at the same time selling agent), marketing in own stores, marketing in hypermarkets and online sales.

In the analyzed companies, of 192, 82 firms have succeeded in maintaining their number of employees, while 110 didn't do so. However is relevant the analysis of the extent in which the investigated companies, grouped by the destination of production, have maintained the number of employees.

Thus, of the 44 firms which export in fullproduct, 31 companies have maintained their number of employees, in the 71 companies that export in lohn system 28 companies maintained their number of employees and of the 77 firms that address the internal market 23 companies maintained their number of employees.

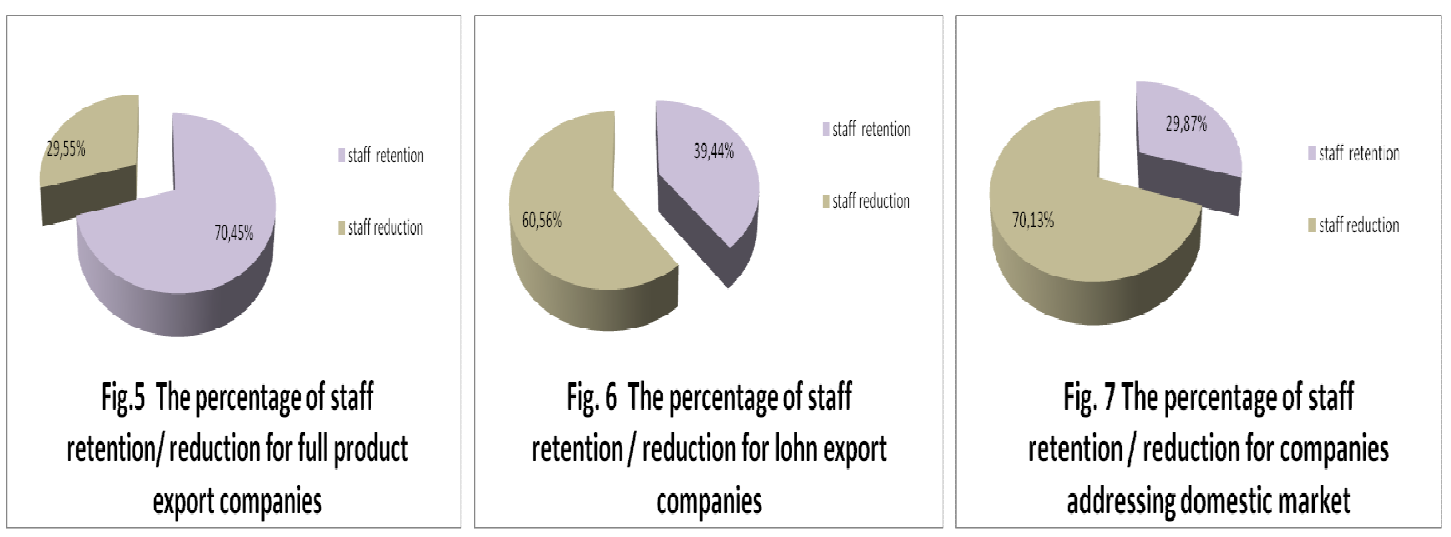

If we analyze the distribution of companies that have maintained number of employees, according to their size, we find that overall (full product export + lohn system + domestic), small firms are those that have managed to maintain number of employees, in proportion of $57 \%$.

Of the 19 small firms carrying out fullproduct export 16 have maintained number of employees (84\%). Of the 9 micro firms which export full-product from the sample, 7 companies have maintained number of employees $(78 \%)$.
Of the 26 small companies that perform the lohn system 12 maintained their staff (46\%), of the 35 micro firms performing the lohn system 14 and maintained their number of employees (40\%). Major exporting companies analyzed have maintained the number of employees in amount of $25 \%$.

Small businesses that address the internal market have kept the staff in proportion of $40 \%$, respectively of the 15 , only six companies have maintained their number of employees. Micro firms and medium-sized companies that address the internal market 
9 Journal of Eastern Europe Research in Business \& Economics

are those with the weakest results in terms of maintaining the number of employees. None of the big companies in the analyzed sample addresses the internal market. Correlation analyses presented above are illustrated in Tables 4 and 5.

Table 4. Distribution of Firms by Size according to the Destination of Production

\begin{tabular}{|c|c|c|c|c|}
\hline $\begin{array}{c}\text { Company size / } \\
\text { Destination of } \\
\text { production }\end{array}$ & $\begin{array}{c}\text { Large (over 250 } \\
\text { employees) }\end{array}$ & $\begin{array}{c}\text { Medium (50- } \\
\text { 249 employees) }\end{array}$ & $\begin{array}{c}\text { Small (10-49 } \\
\text { employees) }\end{array}$ & $\begin{array}{c}\text { Micro (1-9 } \\
\text { employees) }\end{array}$ \\
\hline Full-product & 2 & 14 & 19 & 9 \\
\hline Lohn system & 2 & 8 & 26 & 35 \\
\hline $\begin{array}{c}\text { Domestic } \\
\text { market }\end{array}$ & - & 7 & 15 & 95 \\
\hline TOTAL & 4 & 29 & 60 & 99 \\
\hline
\end{tabular}

Table 5. Distribution of Companies that have Maintained Number of Employees according to the Destination of Production Correlated with their Size

\begin{tabular}{|c|c|c|c|c|}
\hline $\begin{array}{c}\text { Company size / } \\
\text { Destination of } \\
\text { production }\end{array}$ & $\begin{array}{c}\text { Large (over 250 } \\
\text { employees) }\end{array}$ & $\begin{array}{c}\text { Medium (50- } \\
\text { 249 employees) }\end{array}$ & $\begin{array}{c}\text { Small (10-49 } \\
\text { employees) }\end{array}$ & $\begin{array}{c}\text { Micro (1-9 } \\
\text { employees) }\end{array}$ \\
\hline Full-product & 1 & 7 & 16 & 7 \\
\hline Lohn system & - & 2 & 12 & 14 \\
\hline $\begin{array}{c}\text { Domestic } \\
\text { market }\end{array}$ & - & 2 & 6 & 36 \\
\hline TOTAL & 1 & 11 & 34 & 15 \\
\hline
\end{tabular}

Table 6 presents the distribution of firms by the destination of production by development regions, and Table 7 presents the distribution of firms that maintained the number of employees according to the output destination by regions.

Table 6. Distribution of Companies after the Destination of Production by Development Regions

\begin{tabular}{|c|c|c|c|c|c|c|c|c|}
\hline $\begin{array}{c}\text { Development } \\
\text { region / } \\
\text { Destination } \\
\text { of } \\
\text { production }\end{array}$ & $\begin{array}{c}\text { North- } \\
\text { West }\end{array}$ & $\begin{array}{c}\text { North- } \\
\text { East }\end{array}$ & West & Cen-tre & $\begin{array}{c}\text { South- } \\
\text { West }\end{array}$ & $\begin{array}{c}\text { South- } \\
\text { East }\end{array}$ & $\begin{array}{c}\text { South } \\
\text { Bucharest- } \\
\text { Ilfov }\end{array}$ \\
\hline Full-product & 12 & 3 & 8 & 12 & - & - & 1 & 8 \\
\hline Lohn system & 8 & 9 & 8 & 7 & 12 & 12 & 10 & 5 \\
\hline $\begin{array}{c}\text { Domestic } \\
\text { market }\end{array}$ & 10 & 16 & 7 & 7 & 2 & 13 & 13 & 9 \\
\hline TOTAL & 30 & 28 & 23 & 26 & 14 & 25 & 24 & 22 \\
\hline
\end{tabular}


Table 7. Distribution of Companies that have Maintained the Number of Employees by the Destination of Production on Development Regions

\begin{tabular}{|c|c|c|c|c|c|c|c|c|}
\hline $\begin{array}{c}\text { Development } \\
\text { region / } \\
\text { Destination } \\
\text { of } \\
\text { production }\end{array}$ & $\begin{array}{c}\text { North- } \\
\text { West }\end{array}$ & $\begin{array}{c}\text { North- } \\
\text { East }\end{array}$ & West & Cen-tre & $\begin{array}{c}\text { South- } \\
\text { West }\end{array}$ & $\begin{array}{c}\text { South- } \\
\text { East }\end{array}$ & $\begin{array}{c}\text { South } \\
\text { Bucharest- } \\
\text { Ilfov }\end{array}$ \\
\hline Full-product & 9 & 1 & 5 & 9 & - & - & 1 & 6 \\
\hline Lohn system & 4 & 3 & 4 & 3 & 2 & 4 & 5 & 3 \\
\hline $\begin{array}{c}\text { Domestic } \\
\text { market }\end{array}$ & 3 & 2 & 3 & 3 & - & 3 & 4 & 5 \\
\hline TOTAL & 16 & 6 & 12 & 15 & 2 & 7 & 10 & 14 \\
\hline
\end{tabular}

If we analyze the distribution of companies that have maintained the number of employees, by development regions, we find that the best results were registered by companies in Bucharest-Ilfov (64\%), Central (58\%), NorthWest (53\%) and West (52\%). The South region has maintained $42 \%$ of staff. The worst results in the extent to which firms maintained staff were obtained by companies in the SouthWest (14\%). Companies in the SouthEast and NorthEast maintained the staff in proportion of $28 \%$ and $21 \%$.

The only company that performs full-product export in the South was able to maintain staff. The companies performing full-product export from the Center, Northwest and Bucharest-Ilfov managed to keep their employees in proportion of $75 \%$. The companies in the western region maintained the staff in proportion of $63 \%$, while those in the Northeast with $33 \%$. None of the companies in the South West and South East from the analyzed sample perform fullproduct export. Moreover, the South-West concentrates the lowest number of clothing companies in Romania.

The companies performing in the BucharestIlfov region lohn system managed to keep staff in proportion of $60 \%$. The NorthWest, West and South were able to keep their employees at a rate of $50 \%$, followed by those from the Central region of $43 \%$, and those in the NorthEast and SouthEast with
$33 \%$. The lowest percentage is recorded in the SouthWest namely $17 \%$.

Companies addressing internal market are those that have the weakest results in terms of maintaining the number of employees in the total analyzed sample. Thus, the weights are: North-East (13\%), South-East (23\%), South (31\%), and North-West (30\%) at maintaining the personnel. At neither of the 2 companies addressing the internal market, in the SouthWest region, was the staff kept.

In contrast, firms that addressed the internal market in the Bucharest-Ilfov region managed to maintain employees at a rate of $56 \%$. Companies in the West and Centre kept the staff at a rate of $43 \%$.

Questions regarding the strategies used by firms that export full-product and have managed to keep the number of employees shows that they mostly serve niche markets, namely: sportswear (25 firms), eco (3 firms) and that of military uniforms (1 firm). The other two companies which export full product and kept the number of employees produces super premium lingerie (Fig.8).

Two sportswear companies serving the niche, one that serves the eco niche and the company that manufactures military uniforms and one that produces lingerie are joint ventures. 
Companies that exploit the sportswear niche (mainly small and micro firms) produce mostly top technical items. These are mainly: Ski suits (23), equipment for cyclists (1 small company in the Central region) and sports apparel for the segment of paragliding and hang gliding (1 micro firm in the Central region). Most companies which exploit the niche sportswear use the technical materials, known as "intelligent textiles", and fabric laminated with waterproof and breathable membranes (micro porous and hydrophilic) of the range Gore Tex, Dermizax, Soft Shell fabric, Wind Stoppers, Toray, and Schoeller. These companies have invested in the latest equipment and technology. Products sold by these manufacturers are innovative, incorporating much technology and functionality.

Companies that exploit the eco niche produce:

- The joint venture (small business, NorthWest) - Hemp garments for women and men;

- One of flax and hemp garments for women and men (micro firm in the western region) who exploit local traditions and cultural influences;

- One of eco clothes made out of cotton for babies (micro firm in the Central region).

The joint venture company producing military uniforms has four factories in the Northeast region, is large business, uses Gore-Tex fabric and produces uniforms for police, fire, and finance guard for the authorities of the country to which it exports.

Companies that produce lingerie are:

- One of the NorthWest regions, middle firm;

- The joint venture of the Bucharest-Ilfov, small firm.

It is noted that most firms serving niche markets, exporting full-product and having managed to maintain the number of employees are micro, small and medium firms. All of them have diversified the used distribution channels, focusing on their own distribution. Customers, who purchase from these firms, receive instructions on how to use and maintain the product, several years warranty on the product, and service if necessary.

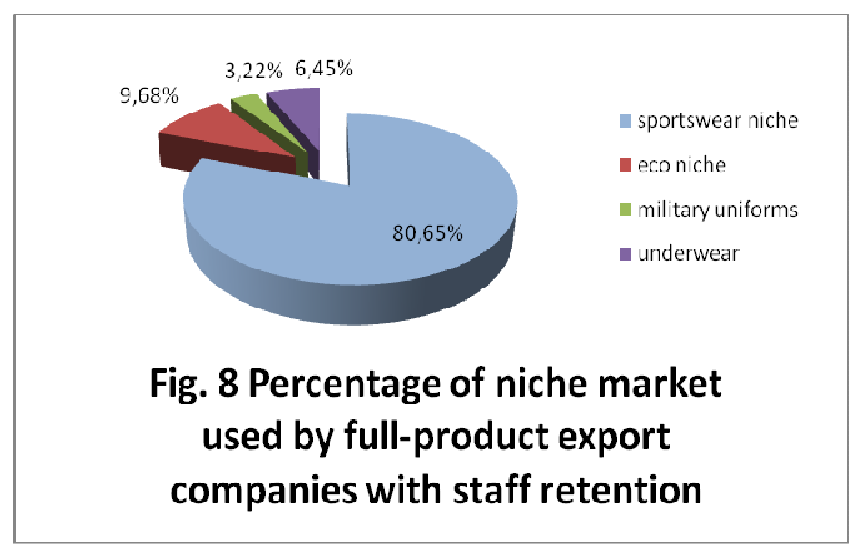

Managers of companies that address internal market have developed their own brands, 3 of them having a portfolio of tradition brands that have been consolidated over time, with a good price-quality ratio, effective promotion and diversified distribution channels. 
The managers of firms that have failed to maintain their number of employees, both those of exporting firms and those of companies that address the domestic market argue that this was a direct effect of the global economic crisis, together with the lack measures to support the producers, of measures to revive the textile industry, suppliers of raw materials and which practically was abolished after 1989, when Romania switched to a market economy.

Three of the 192 sample firms that have managed to create new jobs are:

- The company that capitalizes the market niche of sportswear, paragliding and hang gliding segment;

- joint venture company that exploit the market niche of military uniforms;

- One of the companies that exploit the eco niche, namely the outfits for kids.

It appears that all three full-product exporting firms, exploiting niche markets, 2 are micro, one in the Center, one of them NorthEast and one is a large joint venture company of the Centre.

III. The future growth of employment in Romanian clothing companies are:

- Accessing the European funds for modernizing the industrial process of SMEs consistent with the Small Business Act for Europe by producers;

- Initiating the collaboration with companies belonging to the four clusters in the field of in the textile-clothing industry found in Romania (ASTRICO cluster in Northeast, Romanian Textile Concept cluster in Bucharest-Ilfov, Traditions Manufacture Future cluster in Southeast and Transylvania Textiles\&Fashion cluster in the Centre) to: conduct research contracts related to occupancy and skills, the achievement of joint projects implemented by the Ministry of Labor, Family and Social
Protection about counseling, employment, changing attitudes, removal of barriers, accessibility, training, inclusion, especially since the study revealed a larger financial and logistical potential especially of companies in the development regions of Centre and Bucharest-Ilfov, but also of the NorthEast;

- Creating their own brands both for export and for the domestic market;

- Niche market capitalization, given that in the overall garment industry in Romania most businesses are micro and small firms, followed by medium, with low financial power;

- Entering unexplored niches Romanian producers such as attractive garments for overweight people, for the elderly who have average and high income;

- Initiating programs to improve young entrepreneurs, to start a business and improve competitiveness;

- Identifying new skills requirements (quantitative and qualitative) articulated with innovation and development strategies;

- Improving the promoting of exports of clothing through participation in international fairs and exhibitions;

- Intensification of product promotion and diversification of the distribution channels used;

- Sharing best practices and experiences with other Member States and non-EU to try to limit the effects of the economic crisis.

\section{Conclusions}

The study revealed a low level of employment in the clothing industry in Romania. The study revealed a high degree of maintenance, in the context of global 
13 Journal of Eastern Europe Research in Business \& Economics

economic crisis, a high employment in exporting firms, especially those that export full-product, a higher potential of the Bucharest-Ilfov, NorthWest, Central, NorthEast and West development regions, of the micro, small and medium firms. The study also identified three companies in the sample that have created new jobs in the Central region and in the NorthEast, firms that export full-product. The future directions of increasing employment in the clothing Romanian companies were identified.

\section{References}

Boge, A. (2012). "Consumatorii nu știu ce vor," Dialog Textil, (1), S.C. Modern Media Group S.R.L, 25.

Kanter, R. M. (2005). 'Frontierele Managementului,' Ed. Meteor Press, Bucureşti.

Popescu, D., Bâgu, C., Popa, I. \& Hâncu, D. (2009). 'Posibilităţi de Realizare a Exporturilor Integrale Ale Firmelor De Confecții De Îmbrăcăminte Din România În Contextul Crizei Economice Mondiale,' Industria Textilă, (6), 335.

Popescu, D. \& Popa, I. 'New Forms of Retail Case Study of the Apparel Retail Industry in Romania,' Proceedings of the 18th Inernational Business Information Management Association (IBIMA), ISBN: 9780-9821489-7-6, 9-10 May 2012, Istambul, Turkey.

Pop, N., Fugaru, A. \& Ioan-Franc, V. (2010). Despre criză fără mânie şi cu discernământ, Ed. Expert, Bucureşti.

Turp-Balazs (2012). 'Se Relansează Producţia Din Europa,' Dialog Textil, 1., 10.

http://ec.europa.eu/enterprise/policies/sme /market-access/internationalisationen.htm, retrieved, December 21, 2010 